\title{
Chicken Feathers Waste Management by Microbial as a Sustainable and Tool Environmental Friendly
}

\author{
Amal A. Al Mousa*, Nadine M. S. Moubayed, Amani M. Al Jaloud, Fatima S. Al Khattaf, \\ Noura D. Dahmasha \\ Department of Botany and Microbiology, College of Science, King Saud University, Riyadh, Saudi Arabia \\ Email: *aalmosa@ksu.edu.sa,nmoubayed@ksu.edu.sa, aaljloud@ksu.edu.sa,falkhataf@ksu.edu.sa, 438204570@student.ksu
}

How to cite this paper: Al Mousa, Amal A., Moubayed, N.M.S., Al Jaloud, A.M., Al Khattaf, F.S. and Dahmasha, N.D. (2021) Chicken Feathers Waste Management by Microbial as a Sustainable and Tool Environmental Friendly. Journal of Environmental Protection, 12, 639-653.

https://doi.org/10.4236/jep.2021.129039

Received: August 23, 2021

Accepted: September 25, 2021

Published: September 28, 2021

Copyright (c) 2021 by author(s) and Scientific Research Publishing Inc. This work is licensed under the Creative Commons Attribution International License (CC BY 4.0).

http://creativecommons.org/licenses/by/4.0/

\begin{abstract}
Valorizing chicken feather agro-wastes nowadays is imperative, if these wastes are disposed of without treatment, they could contribute to environmental problems. Conventional methods of processing chicken feathers such as landfilling, chemical treatment and burning are costly, non-time consumable and are toxic to the environment. Microbial hydrolysis, on the contrary, is now considered the main environmental-friendly recycling alternative. Hence, the aim of this study is to isolate keratinolytic bacteria with efficient feather hydrolysis, to optimize some of the physical parameters that could affect both bacterial growth and consequently its degrading ability. Results demonstrated an efficient feather degrading ability of newly identified Bacillus sp. D4 strain isolated from chicken feathers under optimal mesophilic temperature $37^{\circ} \mathrm{C}$, $\mathrm{pH} 8.0$ and $10^{6} \mathrm{CFU} / \mathrm{mL}$ cell size inoculum, interpreted by highest keratin activity $(55.0 \pm 1.35 \mathrm{U} / \mathrm{mL})$ and $(54.3 \pm 1.5 \mathrm{U} / \mathrm{mL})$ respectively and higher total protein content in the cell free supernatant of $0.65 \mathrm{mg} / \mathrm{mL}$. Beyond these parameters values, a moderate enzyme activity was observed at $40^{\circ} \mathrm{C}(35.1 \pm 2$ $\mathrm{U} / \mathrm{mL}), 25^{\circ} \mathrm{C}(30.1 \pm 2 \mathrm{U} / \mathrm{mL})$, similarly at the initial pH $7.5(52.3 \pm 2 \mathrm{U} / \mathrm{mL})$, pH $9.0(49.0 \pm 1.2 \mathrm{U} / \mathrm{mL})$ and pH $10.0(38.2 \pm 1.35 \mathrm{U} / \mathrm{mL})$. Bacillus sp. D4, on the other hand, was not able to tolerate high alkaline $\mathrm{pH}$ value 11.0 nor acidic $\mathrm{pH} 4.0$ and 5.0 and high temperature of $55^{\circ} \mathrm{C}$, correspondingly low enzyme activity was noted $(19.0 \pm 1 \mathrm{U} / \mathrm{mL})$.
\end{abstract}

\section{Keywords}

Chicken Feather Degradation, Keratinolytic Bacteria, Microbial Hydrolysis, Enzyme Activity, Sustainable 


\section{Introduction}

Sustainable consumption and production promote the building of a green economy, quality of life, and long-term recovery for the planet. In contrast, unsustainable linear production and consumption have led to environmental imbalances, climate change, biodiversity extinction, solid waste accumulation, greenhouse gas emissions, and other environmental disasters. Sustainable development has criminalized this unsustainable behavior and made unsustainable production and consumption patterns more sustainable. This ensures sustainable returns with positive effects for both the environment and individuals, modeling a green development strategy that transforms the concept of linear production and consumption into circular production and consumption. Working in a closed-loop, this strategy renders a product's waste raw materials recycle able with innovative technology, resulting in economically valuable materials that contribute to the improvement of the local economy and the elimination of unemployment while simultaneously ensuring zero pollution [1].

Poultry feathers are considered a growing and annoying waste, and in many countries, they are disposed of as environmental waste, which constitutes a burden on landfills in addition to slowing their decomposition.

With increased poultry production, an intense discharge of feather wastes into the environment will be associated. Although the amount of poultry wastes is relatively low compared to other animal wastes; however, feather waste management poses more attention and inquires the development of a right efficient way of reusing poultry feathers and finding the right and effective way to reuse and recycle waste poultry feathers in the future. Feathers constitute about $5 \%-$ $7 \%$ of the chicken weight and they are the main by-product waste estimated for about several million tonnes discarded annually [2]. They are the most ubiquitous and cheapest byproducts with unique properties of warmth retention, sound isolation, high flexibility and compressibility and very low density, in addition, they are composed of about $90 \%$ of keratin as the structural protein [3]. All these features together add to the chicken feather wastes potential applications in different industrial, agricultural and food fields. As feathers are usually mixed with blood and meat [4], therefore their storage is quite important, since they are usually collected and stored in an abundant area before treatment, thus increasing the risk of microbial growth and infections, and may become greater environmental pollutants due to their keratin recalcitrant property [5]. Therefore, many attempts recently have been made for converting chicken feathers wastes, either naturally or chemically treated, into potent heavy metals removal, or absorbent agent from industrial wastewaters, or used as fertilizers, in bedding materials and as feed stocks; however, the process management of feathers wastes depends mainly on the country sanitary and landfilling outlines as well as on the poultry industrial companies and finally on the consumers. In addition, keratin, with its water insolubility, high physical and chemical treatment resistance explained by the formation of recalcitrant polymers hardly degraded by the com- 
mon proteolytic enzymes naming trypsin and pepsin, increases the burden on practicing chicken feather waste processing [6].

It was noted that microbes associated with the chicken feathers could be a potent keratin degrading source to be used in poultry industries [7] by secreting different proteolytic and keratinolytic enzymes. Numerous microorganisms, including bacteria, fungi and actinomycetes, have been isolated from different keratin-rich environments and have been used as keratin degrading materials [8]. Quite a few bacteria have been screened and identified from keratin-rich environments particularly poultry feathers and have been tested for their potential keratin degrading activity [9], due to their ease of growth and their ability to produce new keratonyltic enzymes with unique characteristics of optimal $\mathrm{pH}$ ranging from 5.5 [10] to 12.5 [11] and an optimal temperature from $30^{\circ} \mathrm{C}$ [12] to $100^{\circ} \mathrm{C}$ [13]. Bacillus strains with keratinolytic activity prevailed over any other bacterial genus, they were considered as the first peptidases with keratinolytic activity [14].

Despite the interest in the microbial keratin enzyme hydrolysis, however, the mechanism is not yet fully understood. It was noted that a synergistic enzymatic activity occurs leading to keratin degradation [5] [15] [16]. Disruption of the keratin structure by keratinases is an essential step in breaking down keratin, mainly by disrupting the disulfide bridges in the keratin structure by disulfide bond reductases and intracellular cysteine dioxygenase [5]. In nature, these mechanisms occur with the assessment of auxiliary proteins, like lytic polysaccharide monooxygenases (LPMOs) [5]. Other studies, however, reported that some peptidases with keratin degrading activity do not require the assistance of disulfide reducing enzymes. For example, Pillai et al. [17] isolated a serine protease from Bacillus subtilis P13 with reductase and keratinase activities capable of decomposing feathers. On the other hand, He et al. [18] indicated the presence of 4 enzymes isolated from Bacillus subtilis involved in keratin hydrolysis. All these findings indicated that keratin degradation can be done successfully with microorganisms; indeed, the aim of many researchers recently is to implement the microbial conversion of feathers into value-added products in most poultry companies.

Therefore, the aim of this manuscript is to isolate keratinolytic bacteria with efficient feather hydrolysis, to optimize some of the physical parameters that could affect both bacterial growth and consequently its degrading ability.

\section{Materials and Methods}

\subsection{Bacterial Isolation from Chicken Feathers}

Collected chicken feathers (white and white/black) from a poultry farm located in Dhruma, Riyadh, Saudi Arabia, were washed from any impurities and debris several times with sterile distilled water. Washed feathers were then used for the bacterial isolation with two methods: 1) Direct swabbing on the feather skin surface with $0.1 \%$ tween $80 ; 2$ ) Washing $0.1 \mathrm{~g}$ of feathers with $0.1 \%$ tween 80 
with agitation for $30 \mathrm{~min} .0 .1 \mathrm{~mL}$ of the resulting suspension was inoculated into tryptic soy agar plates (TSA). Plates were incubated at $37^{\circ} \mathrm{C}$ for $18-24 \mathrm{hrs}$.

\subsection{Screening of Proteolytic Bacteria}

Presumptive keratinolytic isolates were selected, identified based on their morphology, and gram staining, were screened preliminary for proteolytic activity when inoculated on skimmed milk agar plates ( $8 \%$ skimmed milk and $2 \%$ agar). The bacterial isolate with the highest clear zone (halo zone) measured in $\mathrm{mm}$ was considered as the most effective degrading isolate and was selected for further keratinolytic analysis, where it was cultured in $500 \mathrm{~mL}$ liquid feather medium (FM) composed of the following (w/v): $0.5 \mathrm{~g} \mathrm{MgSO}_{4}, 0.05 \mathrm{~g} \mathrm{KH}_{2} \mathrm{PO}_{4}, 0.005$ $\mathrm{g} \mathrm{FeSO}_{4}, 0.05 \mathrm{~g} \mathrm{CaCl}_{2} 0.25 \mathrm{~g}$ yeast extract and $5.0 \mathrm{~g}$ of washed chicken feathers (CF). Cultures were then incubated in a rotary shaker $(180 \mathrm{rpm})$ for 4 days at $37^{\circ} \mathrm{C}$, centrifuged at $10,000 \mathrm{rpm}$ for $10 \mathrm{~min}$ at $4^{\circ} \mathrm{C}$, and the supernatant was stored at $4^{\circ} \mathrm{C}$ for further analysis.

\subsection{Bacterial Identification with DNA Sequencing}

All four keratin degrading isolates obtained on skimmed milk agar plates were identified based on the sequence of the 16srRNA gene. First, the DNA was extracted following the instructions of the pure link mini prep genome kit (Invitrogen, USA). Both DNA concentration and quality were determined using the Genova nanodrop (Italy). The product was amplified by PCR using the universal primer set 1429R (5'-AAGGAGGTGATCCAGCCGCA-3') and 24F (5'-AGAGTTTGATCCTGGCTCAG-3') [19]. A total volume of $25 \mu \mathrm{L}$ PCR reaction was carried in Genepro thermal cycler (Bioer, China); using the GoTaq green Master Mix (Promega, USA) 12.5, $0.125 \mu \mathrm{L}$ of each of the primers forward and reverse of $10 \mu \mathrm{mol}$ concentration, $10.25 \mu \mathrm{L}$ of RNAse DNAse free water and $2 \mu \mathrm{L}$ DNA. The cycling parameters were as follows: initial denaturation for 2 min at $94^{\circ} \mathrm{C}$ followed by 35 cycles of $94^{\circ} \mathrm{C}$ for $15 \mathrm{sec}, 63^{\circ} \mathrm{C}$ for $1 \mathrm{~min}$ as for the annealing of each primer, $72^{\circ} \mathrm{C}$ for $2 \mathrm{~min}$ and a final elongation step at $72^{\circ} \mathrm{C}$ for $5 \mathrm{~min}$. the amplified product was observed on 1.5\% agarose gel electrophoresis where samples were compared to the positive strain Bacillus subtilis ATCC 6633 showing all bands at about $1500 \mathrm{bp}$.

\subsection{DNA Sequencing}

PCR products were then purified using Qiagen QIA 250 Qiagen purification kit (Germany) and sequenced using the applied biosystem sequence analyzer (Spain). According to the manufacturer's instructions, ABI PRISM ${ }^{\circledR}$ BigDye $^{\mathrm{TM}}$ Terminator Cycle Sequencing Kit (version 3.1) was used with the same set of primers previously applied in the amplification reactions $1429 \mathrm{R}$ and 24F. The National Centre for Biotechnology Information (NCBI-BLAST) software was used to identify the DNA sequence identity, accession numbers were given and the evolutionary relationship between the $16 \mathrm{~S}$ rRNA genetic marker of the standard 
strain used as a positive control.

\subsection{Phylogenetic Tree}

Phylogenetic analysis of the isolate in study was performed by the neighbor joining method using the Mega X [20]. The 16S rRNA gene sequence of the presumptive strain was compared to the National Center for Biotechnology Information (NCBI) GeneBank using BLAST (Basic Local Alignment Search Tool).

\subsection{Optimization of the Bacterial Feather Degradation}

The ability of the selected isolate to degrade the chicken feather was optimized according to the determination of significant parameters influencing the process particularly the size of the bacterial inoculum, incubation time, temperature and the $\mathrm{pH}$. Each parameter was observed and optimized independently (one variable at a time) during 4-day culture carried out in $50 \mathrm{~mL} 2 \%(\mathrm{w} / \mathrm{v}$ ) liquid feather medium, where feathers are the sole keratin substrate. Cultures were all incubated in a rotary shaker at $180 \mathrm{rpm}$ and readings of the best feather hydrolysis activity were performed at $280 \mathrm{~nm}$. Following each culture condition, the culture broth was centrifuged at $10,000 \mathrm{rpm}$ for $10 \mathrm{~min}$ at $4^{\circ} \mathrm{C}$, and the supernatant was collected as the crude enzyme to be used for subsequent analysis.

First different inoculation size of $10^{6} \mathrm{CFU} / \mathrm{mL}$ and $10^{9} \mathrm{CFU} / \mathrm{mL}$ of overnight cultured feather degrading bacterium were used to determine the best degrading activity. Following the inoculum size determination, the crucial parameters, temperature and $\mathrm{pH}$ were evaluated. As such different incubation temperatures, ranging from $25^{\circ} \mathrm{C}$ to $55^{\circ} \mathrm{C}$, were performed. Similarly, different $\mathrm{pH}$ values from the initial $\mathrm{pH}$ (7.5) ranging from 4.0 to 11.0 were applied, always for optimal bacterial chicken feather degradation.

\subsection{Keratinase Activity Assay}

Keratinase activity was determined according to Gradisar et al. [21] with slight modification. Where $1 \mathrm{~mL}$ of the crude enzyme was diluted in $2 \mathrm{~mL}$ Tris $\mathrm{HCl}$ buffer $(0.05 \mathrm{M}, \mathrm{pH} 8)$ and then 10 grams of feather powder were added as the keratin substrate. The mixture was incubated at $37^{\circ} \mathrm{C}$ for $1 \mathrm{~h}$ in a water bath (GFL, Germany). The enzymatic activity was stopped by adding $2 \mathrm{~mL}$ of $20 \%$ tricloroacetic acid (TCA), centrifugation was applied again at 10,000 rpm for $10 \mathrm{~min}$, and the absorbance of the obtained supernatant was recorded at $280 \mathrm{~nm}$ and compared to the control mixture (20\% TCA and the crude enzyme), where 0.01 increase of corrected absorbance at $280 \mathrm{~nm}$ with the control was considered as 1 unit $(\mathrm{U} / \mathrm{mL})$ of keratinase activity under the experimental conditions.

\subsection{Feather Hydrolysate and Soluble Protein Determination}

Further to optimal culture conditions determination, feather hydrolysate was obtained and was subjected to autoclaving at $121^{\circ} \mathrm{C}$ for $15 \mathrm{~min}$. The sample was centrifuged and its total protein concentration was quantitated according to 
Bradford method by extrapolating from the standard protein curve constructed of different bovine serum albumin concentrations [22]. A stock solution of bovine serum albumin (BSA) $1 \mathrm{mg} / \mathrm{mL}$ was prepared and a two-fold serial dilution was performed using a 96 microtiter well plate. Briefly $100 \mu \mathrm{L}$ of BSA were added to $100 \mu \mathrm{L}$ phosphate buffer solution (PBS) and then $100 \mu \mathrm{L}$ were serially diluted. The first well was used as the positive control and the last well as the negative control. All wells were inoculated with $30 \mu \mathrm{L}$ of the treated hydrolysate. Plates were read at $595 \mathrm{~nm}$ and the experiment was repeated 3 times. Statistical analysis (ANOVA) was performed with accepted significance $\mathrm{p}<0.05$.

\section{Results}

\subsection{Bacterial Isolation and Screening of Feather Degrading Activity}

In total six bacterial isolates were obtained: five bacterial isolates from direct swabbing (D1, D2, D3, DT3 and D4) and one from tween-80 washing method (W1). All isolates were purified on nutrient agar plates and screened for their feather degrading activity on skimmed milk plates. Almost all selected isolates, except for D1 and D2, exhibited a clear inhibition zone of $50 \mathrm{~mm}$ diameter for D3, $60 \mathrm{~mm}$ for both DT3 and W1 and $63 \mathrm{~mm}$ for D4 (Figure 1). Hence, D4 was considered as the most effective keratinolytic bacterium upon which further analyses were performed.

\subsection{Bacterial Identification}

16SrRNA partial analysis of the bacterial isolates, particularly with hydrolysis activity (D4, W1, and DT3) were given the following accession number MZ701911, MZ701912, MZ701913 except D3 strain, which in comparison to the NCBI gene bank, revealed to belong to the Bacilli sp. the neighbor joining phylogenetic tree of the strains in study indicated their location in the branch comprising Bacillus amyloliquefaciens, Acinetobacter varaiabilis, Bacillus pumilus and Bacillus methylotrophicus (Figures 2(a)-(d)).

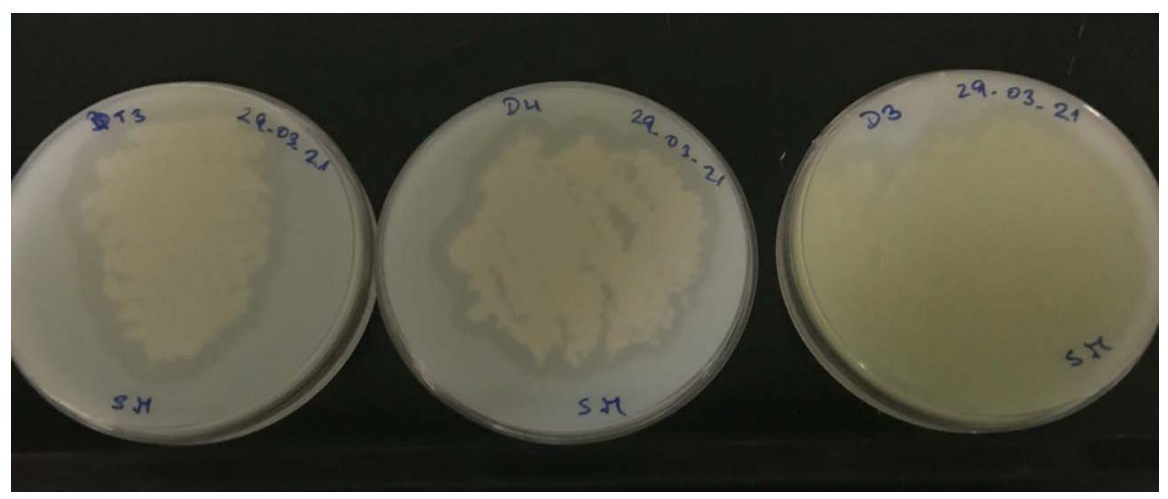

Figure 1. Keratin hydrolysis represented by measured halo zones on skimmed milk agar, where D4 presented the highest clear zone $(63 \mathrm{~mm})$ followed by DT3 $(60 \mathrm{~mm})$ and D3 $(50 \mathrm{~mm})$. W1 is not shown. 


\subsection{Effect of Size Inoculum, Temperature and pH on Keratin Hydrolysis and Keratin Activity}

Results from the present study, indicated that the bacterial size inoculum had a negative effect on the feather degradation. Higher degradation activity was observed with lower inoculum size. Bacillus sp. D4 when inoculated with $10^{6} \mathrm{CFU} / \mathrm{mL}$
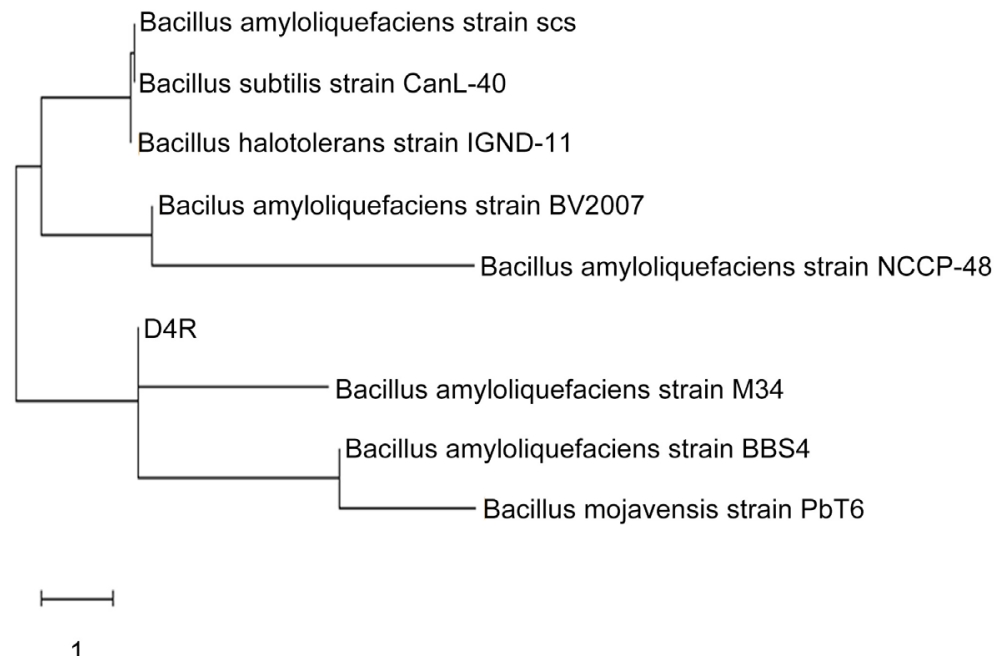

(a)

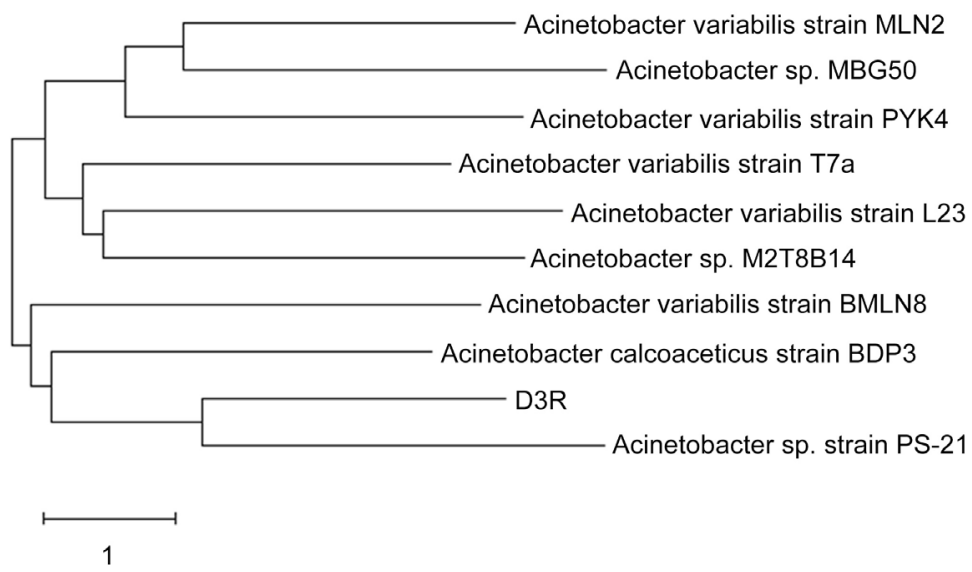

(b)

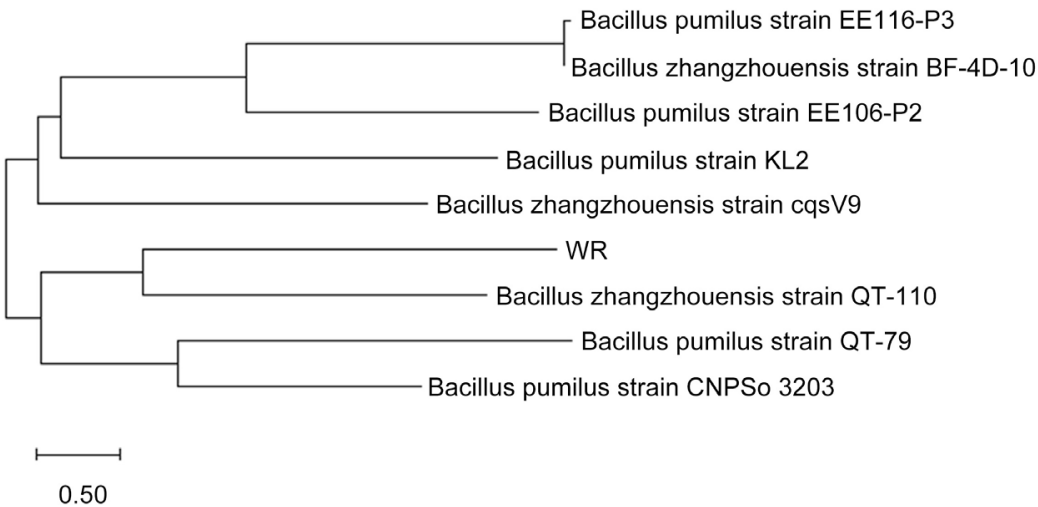

(c) 


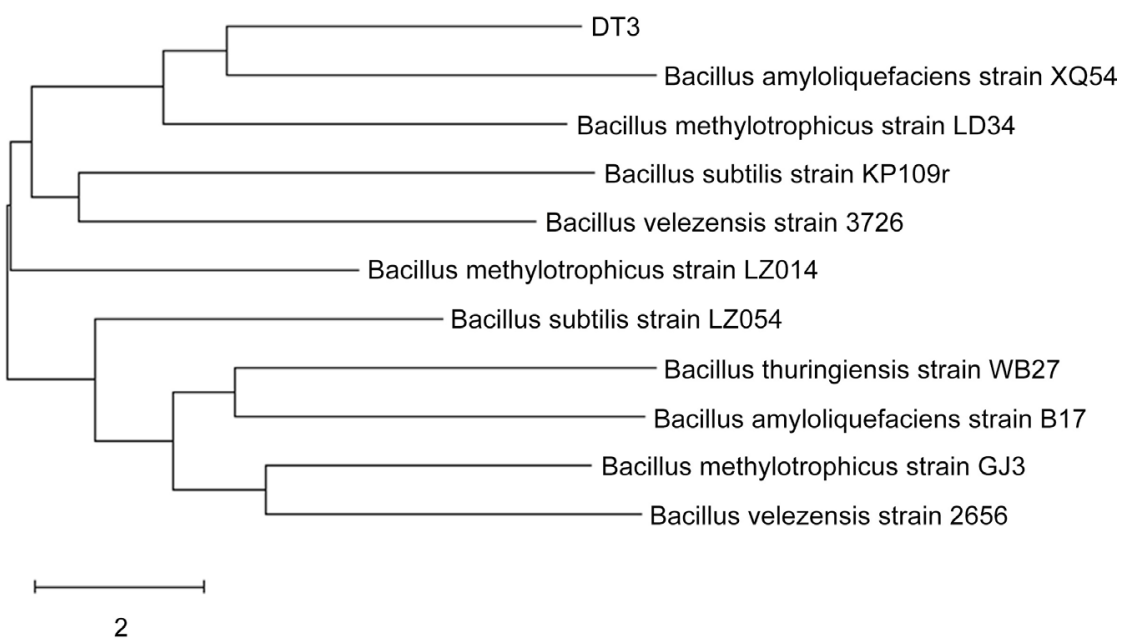

(d)

Figure 2. (a) Phylogenetic tree indicating a position of D4 isolate with the accession number (MZ701911) within Bacillus genus based on 16S rDNA was found to be $97.8 \%$ similar to Bacillus Amyloliquefaciens strain NCCP-48. Phylogenetic tree was built with the neighbor-joining method (Mega X) from the relationships of 16S rDNA sequences between the isolate and closely related type strains. The bar represents the evolutionary distance. (b) Phylogenetic tree indicating a position of D3 isolate within Acinetobactergenus based on $16 \mathrm{~S}$ rDNA. Phylogenetic tree was built with the neighbor-joining method (Mega X) from the relationships of $16 \mathrm{~S}$ rDNA sequences between the isolate and closely related type strains. The bar represents the evolutionary distance. (c) Phylogenetic tree indicating a position of W1 (MZ701913) isolates within Bacillus genus based on 16S rDNA. Phylogenetic tree was built with the neighbor-joining method (Mega X) from the relationships of $16 \mathrm{~S}$ rDNA sequences between the isolate and closely related type strains. The bar represents the evolutionary distance. (d) Phylogenetic tree indicating a position of DT3 (MZ701912) isolates within Bacillus genus based on 16S rDNA. Phylogenetic tree was built with the neighbor-joining method (Mega X) from the relationships of $16 \mathrm{~S}$ rDNA sequences between the isolate and closely related type strains. The bar represents the evolutionary distance.

compared to $10^{9} \mathrm{CFU} / \mathrm{mL}$ revealed the highest keratin degrading activity, observed by a higher viscosity in the medium (Figure 3 ).

Temperature and $\mathrm{pH}$ had different patterns on the chicken feather (CF) degradation. It was noted that with increased temperature D4 had a negligible hydrolysis activity. The optimal keratin enzyme activity was observed at $37^{\circ} \mathrm{C}(55.0$ $\pm 1 \mathrm{U} / \mathrm{mL})$ followed by moderate activity at $25^{\circ} \mathrm{C}(30.1 \pm 2 \mathrm{U} / \mathrm{mL})$ and decreased gradually with higher incubation temperatures $35.3 \pm 2.1 \mathrm{U} / \mathrm{mL}$ at $40^{\circ} \mathrm{C}, 23.1 \pm 1$ $\mathrm{U} / \mathrm{mL}$ at $45^{\circ} \mathrm{C}$, beyond this temperature particularly at $55^{\circ} \mathrm{C}$ low or no bacterial growth was observed and hence low enzyme activity was recorded (19.0 \pm 1 $\mathrm{U} / \mathrm{mL}$ ) (Figure 3 and Figure 4).

$\mathrm{pH}$, on the other hand, indicated a considerable degrading activity with slightly alkaline values. D4 Bacillus sp. exhibited both highest activity and soluble protein content at $\mathrm{pH} 8.0(54.3 \pm 1.5 \mathrm{U} / \mathrm{mL})(0.65 \mathrm{mg} / \mathrm{mL})$ when compared to the initial $\mathrm{pH} 7.5(52.34 \pm 2 \mathrm{U} / \mathrm{mL})$ and $0.53 \mathrm{mg} / \mathrm{mL}$ soluble protein content, then decreased gradually with pH $9(49.4 \pm 1.2 \mathrm{U} / \mathrm{mL}), \mathrm{pH} 10(38.2 \pm 1.35 \mathrm{U} / \mathrm{mL})$ and $\mathrm{pH} 6.7$ 


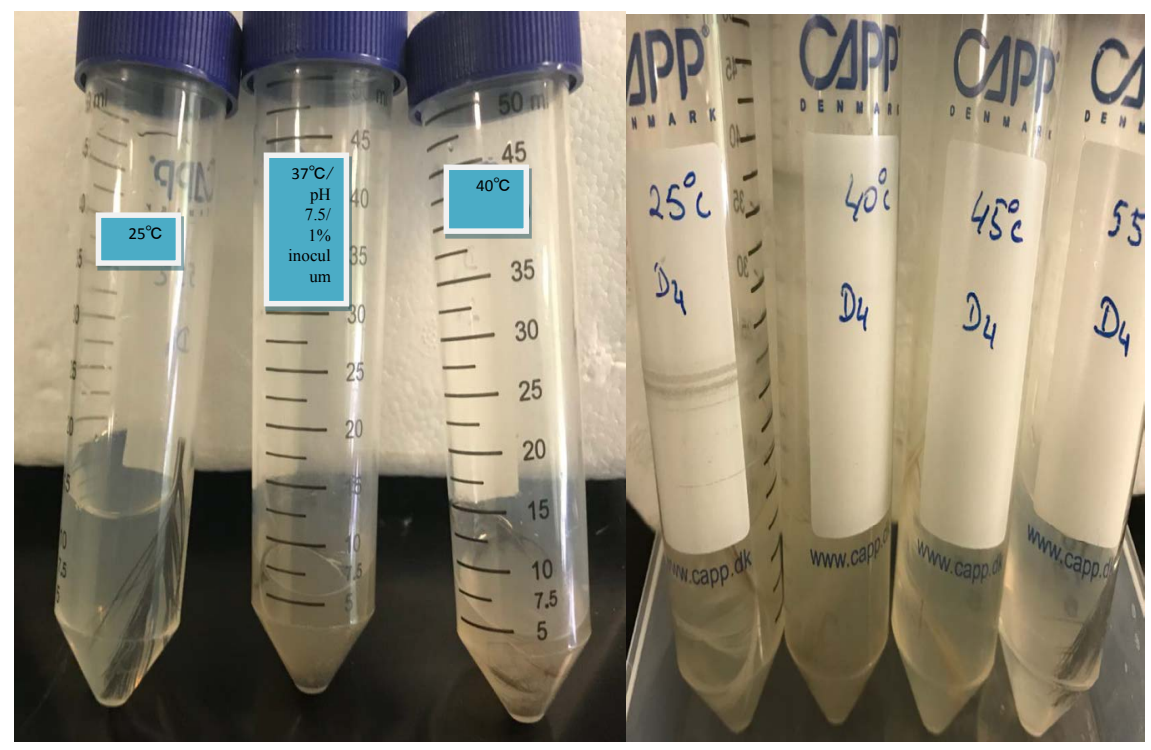

Figure 3. Effect of temperature on Bacillus sp. D4 feather degradation. Efficient feather hydrolysis was observed at $40^{\circ} \mathrm{C}$ and $37^{\circ} \mathrm{C}$ and decreased gradually at $45^{\circ} \mathrm{C}$ and $55^{\circ} \mathrm{C}$ as well as $25^{\circ} \mathrm{C}$.

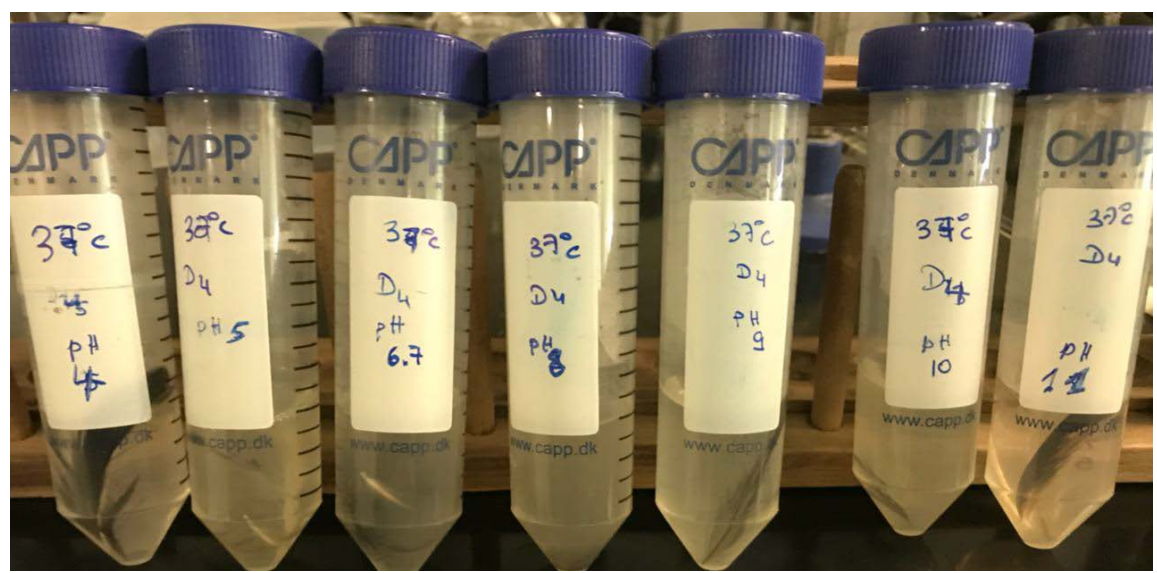

Figure 4. pH effect on Bacillus sp. D4 feather hydrolysis activity. Where optimal degradation activity was recorded at $\mathrm{pH} 8.0$ and $\mathrm{pH} 7.5$ and decreased with higher $\mathrm{pH}$ values $(9.0,10.0)$. No and or low bacterial growth was observed at $\mathrm{pH}$ values $(4.0,5.0$ and 11.0).

(23.0 $\pm 1 \mathrm{U} / \mathrm{mL})$. Oppositely, pH 11.0, 4.0 and 5.0 showed low significant enzymatic activity explained by a non-remarkable bacterial growth (Figure 5 and Figure 6).

\section{Discussion}

Although feathers are rich in amino acids, and hence their hydrolysis can serve as a good protein source for animal nutrition and or for microbial growth, however, their excessive presence, considered as waste, contributes to environmental pollution which requires a quick efficient degrading process. Recently, the focus is on using natural keratinophilic microbes due to their low cost, ease of growth, their good yield of keratinases and the formation of non-toxic byproducts 


\section{Temperature effect}

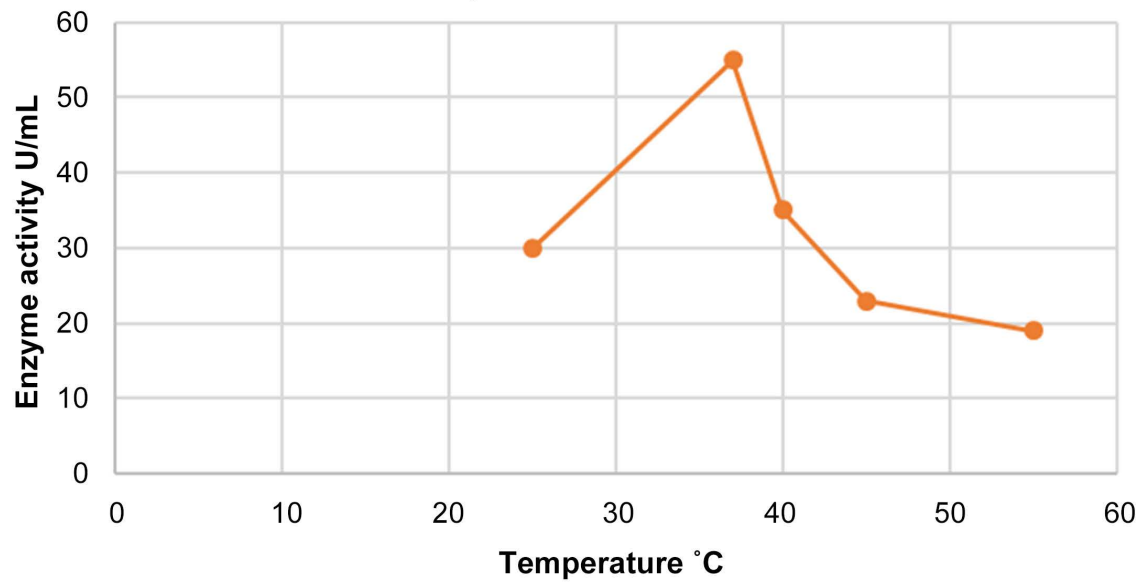

Figure 5. Temperature effect vs the enzyme activity in cell free supernatant. Optimal activity was observed at the mesophilic temperature $37^{\circ} \mathrm{C}$ followed by moderate activity at $40^{\circ} \mathrm{C}$ and $25^{\circ} \mathrm{C}$ respectively and decreased significantly with higher temperature values of $45^{\circ} \mathrm{C}$ and $55^{\circ} \mathrm{C}$.

\section{pH effect vs. enzyme activity}

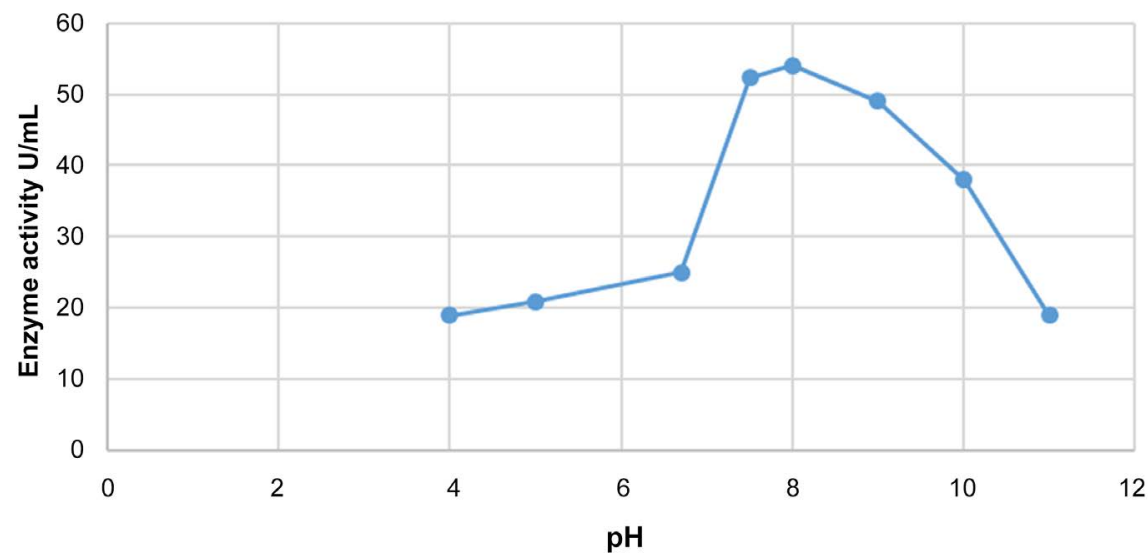

Figure 6. $\mathrm{pH}$ influence on keratin enzyme activity. Higher activity was obtained at $\mathrm{pH} 8.0$ and the initial $\mathrm{pH} 7.5$, beyond these values enzyme activity decreased particularly at $\mathrm{pH}$ $9.0,10.0$ and 6.7. Low enzyme activity was observed at $\mathrm{pH} 11.0$ and the acidic $\mathrm{pH} 4.0$ and pH 5.0 (19.0).

[23] [24]. However, the mechanisms behind this degradation still require further studies. As reported by Nnolim et al. [25], keratinolysis can be catalyzed by a single keratinase, or more efficiently, in synergy with other enzymes such as disulfide reductases to breakdown the disulfide bond, peptidases and trypsin [26].

Previous studies indicated that microorganisms such as bacteria, fungi and actinomycetes have the ability to degrade these wastes by secreting keratinolytic enzymes [7].

Many keratinolytic bacteria have been isolated with a different featherdegrading activity determined by mainly the enzyme yield and activity [27], therefore, enzyme optimization is crucial, due to strain variability. In the present 
study, a novel keratinolytic bacterium (D4) was identified from chicken feathers by DNA sequencing as Bacillus sp. derived from Bacillus amyloliquefaciens, showed a significant keratinolytic activity measured by the largest halo zone (63 $\mathrm{mm}$ ) on skimmed agar plate and an estimation of extracellular kertinase activity. Results revealed an optimal feather degrading activity at a slightly alkaline $\mathrm{pH}$ $8.0(54.3 \mathrm{U} \pm 1.5 \mathrm{U} / \mathrm{mL})$ from the initial $\mathrm{pH} 7.5(52.3 \pm 2.0 \mathrm{U} / \mathrm{mL}), 37^{\circ} \mathrm{C}(55.0 \pm$ $1 \mathrm{U} / \mathrm{mL}$ ) incubation temperature and $10^{6} \mathrm{CFU} / \mathrm{mL}$ bacterial concentration. Bacillus sp. D4 when inoculated with $10^{6} \mathrm{CFU} / \mathrm{mL}$ compared to $10^{9} \mathrm{CFU} / \mathrm{mL}$ revealed the highest keratin degrading activity, observed by a higher viscosity in the culture medium (Figure 3). Nonetheless, an increase beyond these optimal levels has been reported to impact negatively on extracellular keratinase secretion by microorganisms [23]. The hydrolysis activity of the strain in study Bacillus sp. D4 was noted to decrease gradually with $\mathrm{pH} 9.0(49.4 \pm 1.2 \mathrm{U} / \mathrm{mL})$ and $10.0(38.2 \pm 1.35 \mathrm{u} / \mathrm{mL})$, in agreement with Gupta and Ramnani [28] who reported that most bacterial degrading activity occurred at alkaline $\mathrm{pH}$ from 6.0 to 9.0. Similarly, B. pumilus GRK actively induced feather hydrolysis between $\mathrm{pH}$ 8.0 and 12.0 [29]. Oppositely, pH 11.0 and the acidic $\mathrm{pH}$ values (4.0 and 5.0) inhibited the bacterial growth and hence low enzymatic activity was recorded. This could be explained by an increased ammonium release due to amino acid or peptide deamination from keratin degradation which in its turn caused an increase in the $\mathrm{pH}$ value. Previous studies, on the other hand, reported increased keratinase activity by Bacillus sp. at acidic pH 4.0 and 5.0 where particularly doubled keratinase activity was observed at pH 5.0 [25] [30].

Temperature too was found to highly influence the bacterial keratinolytic activity, where higher growth rate accompanied by efficient feather hydrolysis was observed at the mesophilic temperature $37^{\circ} \mathrm{C}(55.0 \pm 1.5 \mathrm{U} / \mathrm{mL})$, supported by Akhter et al. [31] who demonstrated that higher bacterial growth rate was recorded with mesophilic temperature between $37^{\circ} \mathrm{C}$ and $39^{\circ} \mathrm{C}$. However, moderate hydrolytic activity of Bacillus sp. D4 was found with the studied incubation temperatures in the following order $40^{\circ} \mathrm{C}(35.3 \pm 2.1 \mathrm{U} / \mathrm{mL})>25^{\circ} \mathrm{C}(30.1 \pm 2$ $\mathrm{U} / \mathrm{mL})>45^{\circ} \mathrm{C}(23.1 \pm 1 \mathrm{U} / \mathrm{mL})$, whereas non-remarkable bacterial growth consequently low enzyme activity was observed at $55^{\circ} \mathrm{C}(19.0 \pm 1 \mathrm{U} / \mathrm{mL})$. This finding was consistent was with the findings of Gupta and Ramnini [14] Daroit and Brandelli [32] who suggested that efficient bacterial keratinolytic activity was observed at mesophilic temperatures ranging between $25^{\circ} \mathrm{C}-37^{\circ} \mathrm{C}$. Other studies, on the contrary, indicated efficient feather degradation at increased temperature between $45^{\circ} \mathrm{C}$ and $70^{\circ} \mathrm{C}$ [13] [33]. A similar trend was observed for the total protein content $(0.65 \mathrm{mg} / \mathrm{mL})$ in the cell free supernatant under the alkaline $\mathrm{pH} 8.0$ compared to the initial $\mathrm{pH} 7.5$, thus alkaline conditions could promote keratin feather hydrolysis, liberating as such quantifiable soluble proteins [34]. Based on these initial findings, the isolated Bacillus sp. D4 confirmed its keratinolytic potential on day 4 , at $37^{\circ} \mathrm{C}, \mathrm{pH} 8.0$ and $10^{6} \mathrm{CFU} / \mathrm{mL}$ inoculum size, mainly against raw chicken feathers $(1 \%)(\mathrm{w} / \mathrm{v})$ as the sole keratin substrate in 
the culture medium, however; more elaboration in our coming work will be applied to study further the enzyme optimal conditions, and activity as well as its purification, together with the use of co-cultures of the best keratinolytic isolates (D4 and DT3) to improve both feather decomposition, keratinase yield and activity.

\section{Conclusion}

Bacterial biodegradation of feather waste is a green technology method compatible with the 17 Sustainable Development Goals where a balance is achieved between economic growth and decent work for all as well as environmental protection from pollution solid waste. The present work demonstrated Bacillus sp D4 has proven highly efficient in keratin biodegradation of raw chicken feathers in a short period of time while revealing the optimum medium conditions, and this strain offers a promising of hope its importance in converting waste keratin into valuable products used in biotechnology and multiple industrial fields.

\section{Acknowledgements}

The authors extend their appreciation to the Deanship of Scientific Research at King Saud University for funding this work through research group No (RG1441-419).

Also, the authors would like to thank the Deanship of Scientific Research and RSSU at King Saud University for their technical support.

\section{Conflicts of Interest}

All authors declare no conflict of interest.

\section{References}

[1] Akenji, L. and Bengtsson, M. (2014) Making Sustainable Consumption and Production the Core of Sustainable Development Goals. Sustainability, 6, 513-529. https://doi.org/10.3390/su6020513

[2] da Silva, R.R. (2018) Keratinases as an Alternative Method Designed to Solve Keratin Disposal on the Environment: Its Relevance on Agricultural and Environmental Chemistry. Journal of Agricultural and Food Chemistry, 66, 7219-7221. https://doi.org/10.1021/acs.jafc.8b03152

[3] Adav, S.S., Subbaiaih, R.S., Kerk, S.K., Lee, A.Y., Lai, H.Y., Ng, K.W., et al. (2018) Studies on the Proteome of Human Hair-Identification of Histones and Deamidated Keratins. Scientific Reports, 8, Article No. 1599. https://doi.org/10.1038/s41598-018-20041-9

[4] Tesfaye, T., Sithole, B. and Ramjugernath, D. (2017) Valorisation of Chicken Feathers: A Review on Recycling and Recovery Route-Current Status and Future Prospects. Clean Technologies and Environmental Policy, 19, 2363-2378. https://doi.org/10.1007/s10098-017-1443-9

[5] Lange, L., Huang, Y. and Busk, P.K. (2016) Microbial Decomposition of Keratin in Nature-A New Hypothesis of Industrial Relevance. Applied Microbiology and Biotechnology, 100, 2083-2096. https://doi.org/10.1007/s00253-015-7262-1 
[6] Gupta, R., Sharma, R. and Beg, Q.K. (2013) Revisiting Microbial Keratinases: Next Generation Proteases for Sustainable Biotechnology. Critical Reviews in Biotechnology, 33, 216-228. https://doi.org/10.3109/07388551.2012.685051

[7] Tamreihao, K., Mukherjee, S., Khunjamayum, R., Devi, L.J., Asem, R.S. and Ningthoujam, D.S. (2019) Feather Degradation by Keratinolytic Bacteria and Biofertilizing Potential for Sustainable Agricultural Production. Journal of Basic Microbiology, 59, 4-13. https://doi.org/10.1002/jobm.201800434

[8] Chaturvedi, V., Bhange, K., Bhatt, R. and Verma, P. (2014) Production of Kertinases Using Chicken Feathers as Substrate by a Novel Multifunctional Strain of Pseudomonas stutzeri and Its De-Hairing Application. Biocatalysis and Agricultural Biotechnology, 3, 167-174. https://doi.org/10.1016/j.bcab.2013.08.005

[9] Muthusamy, G., Thangaswamy, S. and Arunprakash, S. (2011) Production of Keratinolytic Enzyme by a Newly Isolated Feather Degrading Bacillus sp. from Chick Feather Waste. International Journal of Pharma and Bio Sciences, 2, 259-265.

[10] Muhsin, T.H. and Aubaid, A.H. (2001) Partial Purification and Some Biochemical Characteristics of Exocellular Keratinase from Trichophyton Mentagrophytes var Erinacei. Mycopathologia, 150, 121-125. https://doi.org/10.1023/A:1010900403141

[11] Rai, S.K. and Mukherjee, A.K. (2011) Optimization of the Production of an Oxidant and Detergent-Stable Alkaline Beta-Keratinase from Brevibacillus sp. Strain AS-S10-11: Application of Enzyme in Laundry Detergent Formulations and in the Leather Industry. Biochemical Engineering Journal, 54, 47-56. https://doi.org/10.1016/j.bej.2011.01.007

[12] Thankaswamy, S.R., Sundaramoorthy, S., Palanivel, S. and Ramudu, K.N. (2018) Improved Microbial Degradation of Animal Hair Waste from Leather Industry Using Brevibacterium luteolum (MTCC 5982). Journal of Cleaner Production, 189, 701-708. https://doi.org/10.1016/j.jclepro.2018.04.095

[13] Nam, G.-W., Lee, D.-W., Lee, H.-S., Lee, N.-J., Kim, B.-C., Choe, E.-A., Hwang, J.-K., Suhartono, M.T. and Pyun, Y.-R. (2002) Native Feather-Degradation by Fervidobacterium islandicum AW-1, a Newly Isolated Keratina Seproducing Thermophilic Anaerobe. Archives of Microbiology, 178, 538-547. https://doi.org/10.1007/s00203-002-0489-0

[14] Brandelli, A. (2008) Bacterial Keratinases: Useful Enzymes for Bioprocessing Agroindustrial Wastes and Beyond. Food and Bioprocess Technology, 1, 105-116. https://doi.org/10.1007/s11947-007-0025-y

[15] Kang, D., Herschend, J., Al-Soud, W.A., Mortensen, M.S., Gonzalo, M., Jacquiod, S. and Sorensen, S.J. (2018) Enrichment and Characterization of an Environmental Microbial Consortium Displaying Efficient Keratinolytic Acitivty. Bioresource Technology, 270, 303-301. https://doi.org/10.1016/j.biortech.2018.09.006

[16] Peng, Z, Zhang, J., Du, G. and Chen, J. (2019) Keratin Waste Recycling Based on Microbial Degradation: Mechanisms and Prospects. ACS Sustainable Chemistry \& Engineering, 7, 9727-9736. https://doi.org/10.1021/acssuschemeng.9b01527

[17] Pillai, P., Mandge, S. and Archana, G. (2011) Statistical Optimization of Production and Tannery Application of a Keratinolytic Serine Protease from Bacillus subtilis P13. Process Biochemistry, 46, 1110-1117. https://doi.org/10.1016/j.procbio.2011.01.030

[18] He, Z., Sun, R., Tang, Z., Bu, T., Wu, Q., Li, C. and Chen, H. (2018) Biodegradation of Feather Waste Keratin by Keratin-Degrading Strain Bacillus subtilis 8. Journal of Microbiolog and Biotechnology, 28, 314-322. https://doi.org/10.4014/jmb.1708.08077 
[19] Moubayed, N.M.S., Bhat, R.S., Al Farraj, D., Al Dihani, N., El Ansary, A. and Fahmy, R.M. (2019) Screening and Identification of Gut Anaerobes (Bacteroidetes) from Human Diabetic Stool Samples with and without Retinopathy in Comparison to Control Subjects. Microbial Pathogenesis, 129, 88-92. https://doi.org/10.1016/j.micpath.2019.01.025

[20] Kumar, S., Stecher, G., Li, M., Knyaz, C. and Tamura, K. (2018) MEGA X: Molecular Evolutionary Genetics Analysis across Computing Platforms. Molecular Biology and Evolution, 35, 1547-1549. https://doi.org/10.1093/molbev/msy096

[21] Gradisar, H., Friedrich, J., Križaj, I. and Jerala, R. (2005) Similarities and Specificities of Fungal Keratinolytic Proteases: Comparison of Keratinases of Paecilomyces marquandii and Doratomyces microsporus to Some Known Proteases. Applied and Environmental Microbiology Journal, 71, 3420-3426.

https://doi.org/10.1128/AEM.71.7.3420-3426.2005

[22] Bradford, M.M. (1976) A Rapid and Sensitive Method for the Quantitation of Microgram Quantities of Protein Utilizing the Principle of Protein-Dye Binding. Analytical Biochemistry, 72, 248-254. https://doi.org/10.1016/0003-2697(76)90527-3

[23] Bhari, R., Kaur, M., Singh, R.S., Pandey, A. and Larroche, C. (2018) Bioconversion of Chicken Feathers by Bacillus aerius NSMk2: A Potential Approach in Poultry Waste Management. Bioresource Technology Reports, 3, 224-230. https://doi.org/10.1016/j.biteb.2018.07.015

[24] Menon, S., Savur, B., Kasat, D., Mavani, U., Singh, S. and Rane, M. (2020) Management and Utilization of Keratin Waste-A Review. International Journal of Advance Research, Ideas and Innovations in Technology, 6, 511-515.

[25] Nnolim, N.E., Udenigwe, C.C., Okoh, A.I. and Nwodo, U.U. (2020) Microbial Keratinase: Next Generation Green Catalyst and Prospective Applications. Frontiers in Microbiology, 11, Article No. 580164. https://doi.org/10.3389/fmicb.2020.580164

[26] Nnolim, N.E., Okoh, A.I. and Nwodo, U.U. (2020) Proteolytic Bacteria Isolated from Agro-Waste Dumpsites Produced Keratinolytic Enzymes. Biotechnology Reports, 27, Article No. e00483. https://doi.org/10.1016/j.btre.2020.e00483

[27] Cai, C. and Zheng, X. (2009) Medium Optimization for Keratinase Production in Hair Substrate by a New Bacillus subtilis KD-N2 Using Response Surface Methodology. Journal of Industrial Microbiology and Biotechnology, 36, 875-883. https://doi.org/10.1007/s10295-009-0565-4

[28] Gupta, R. and Ramnani, V. (2006) Microbial Keratinases and Their Prospective Applications: An Overview. Applied Microbiology and Biotechnology, 70, 21-33. https://doi.org/10.1007/s00253-005-0239-8

[29] Reddy, M.R., Yuvraj, C., Bee, H. and Sathi Reddy, K. (2017) Effective Feather Degradation and Keratinase Production by Bacillus pumilus GRK for Its Application as Bio-Detergent Additive. Bioresource Technology, 243, 254-263. https://doi.org/10.1016/j.biortech.2017.06.067

[30] Kim, J.M., Lim, W.J. and Suh, H.J. (2001) Feather-Degrading Bacillus Species from Poultry Waste. Process Biochemistry, 37, 287-291.

https://doi.org/10.1016/S0032-9592(01)00206-0

[31] Akhter, M., Wal Marzan, L., Akter, Y. and Shimizu, K. (2020) Microbial Bioremediation of Feather Waste for Keratinase Production: An Outstanding Solution for Leather Dehairing in Tanneries. Microbiology Insights, 13, Article ID: 1178636120913280. https://doi.org/10.1177/1178636120913280

[32] Daroit, D.J. and Brandelli, A. (2014) A Current Assessment on the Production of Bacterial Keratinases. Critical Reviews in Biotechnology, 34, 372-384. 
https://doi.org/10.3109/07388551.2013.794768

[33] Gurav, R.G. and Jadhav, J.P. (2013) Biodegradation of Keratinous Waste by Chryseobacterium sp. RBT Isolated from Soil Contaminated with Poultry Waste. Journal of Basic Microbiology, 53, 128-135. https://doi.org/10.1002/jobm.201100371

[34] Stiborova, H., Branska, B., Vesela, T., Lovecka, P., Stranska, M., Hajslova, J., Jiru, M., Patakova, P. and Demnerova, K. (2016) Transformation of Raw Feather Waste into Digestible Peptides and Amino Acids. Journal of Chemical Technology \& Biotechnology, 91, 1629-1637. https://doi.org/10.1002/jctb.4912 